\title{
TRENDS IN DEVELOPMENT OF TRACTOR FLEET IN LATVIA
}

\author{
Dainis Viesturs, Nikolajs Kopiks \\ Latvia University of Agriculture \\ uzc@apollo.lv
}

\begin{abstract}
The article analyses the development of the fleet of tractors in the period 2000-2015. Major brands of tractors registered in Latvia have been clarified. It has been established that, alongside with the purchase of new tractors meeting the EU regulations, there are still approximately 55 thousand tractors enlisted in the State Register, which are produced in the CIS countries and are older than 20 years, constituting about $65 \%$ of the total number of tractors. The registration procedure allows a great number of worn-out tractors being in the Register. The average number of the tractors purchased a year is 650.8 new tractors, or 9762 new tractors during the period. The average age of the registered tractors is 24.1 years, and it is gradually increasing, as a result of which the technical condition of the tractor fleet is deteriorating - in the recent years only 33-34 \% of the total number of tractors were in good technical condition. However, the production of goods for the market takes place using highly efficient contemporary machines, the worn-out tractors performing a small amount of work on small peasant farms and on private plots around the farmhouse. A methodology has been worked out for the estimation of the adequate number of tractors for timely cultivation of the areas under agricultural crops. The methodology is based on the calculation of the total increase in the engine power of the tractor fleet per years and its comparison with the increase in the areas sown per years. It is assumed that $10 \%$ of the sowing areas are cultivated by worn-out tractors, but $7.5 \%$ of the new tractor power is required for the replacement (amortisation) of the worn-out tractors. We consider that the increase in the total power should compensate the increase in the sowing areas. It has been found that during the period the total power has grown 1.48 times, the area sown increasing in the same period approximately 1.34 times. Specific power has also been calculated in $\mathrm{kW}^{\cdot} \mathrm{ha}^{-1}$, which is considered by several authors as a criterion for the estimation of the tractor adequacy, as well as its variations in a 15 year period. The specific power has increased 1.18 times but the average weighted power of a new tractor -1.5 times. The increase in the total power of the tractor fleet compensates the increase in sowing areas and even exceeds it a little. The average specific power $\mathrm{kW} \cdot \mathrm{ha}^{-1}$ can be regarded as relatively high, and a decline in this indicator is possible in the future. As the replacement of the worn-out machines will be necessary, and further increase in the sowing areas is expected, upgrading of the tractor fleet should be continued at approximately the same rate - by purchasing, on the average, 600 to 700 new tractors every year.
\end{abstract}

Keywords: fleet of tractors, power, technical condition, sowing areas.

\section{Introduction}

The areas of agricultural lands in Latvia have been increasing every year as well as the production of the products of the field and animal husbandry. For instance, in the period 2000-2015 the areas under cereals and canola have increased 1.7 times, total increase being almost two times; the production of milk increased 1.2 times, the production of meat -1.4 times [1].

There is also growth in the production of other agricultural products. Such production intensification requires also corresponding increase in the efficiency of the fleet of tractors as an important means of production. Data about the registered tractors by their brands and models, data about the technical inspections of tractors, as well as data about the tractors purchased during a year by their brands and models have been registered every year by the State Technical Supervision Agency (STSA) [2]. Data about the sowing area of agricultural crops can be obtained from two sources - the materials of the Central Statistics Board [1] and the Rural Support Service [3].

Several authors have conducted investigations in the age structure of the tractor fleet and its usage efficiency on the farms of various sizes [4-6]; yet there are no investigations about the total power of the tractor fleet, the dynamics of its development and adequacy for the cultivation of the increasing sowing areas. The purpose of the article is to estimate the updating progress of the fleet of tractors and its technical condition in the period 2000-2015, as well as to work out a methodology for the estimation of the power variations of the tractor fleet in this period, and to characterise these variations in comparison with the growing amount of the sowing areas of agricultural crops and the amount of the product.

Studies about the adequacy of combines for harvesting made by the authors in the previous year were partly used for the elaboration of the methodology [7]. 


\section{Materials and methods}

Intensive updating of the tractor fleet started in Latvia after joining the EU in the year 2004 due to the availability of structural funds, there was substantial increase in the purchase of modern tractors. However, significant trading in tractors made in the European countries began in Latvia already in 1996 since the establishment of state subsidies for agriculture, including for the purchase of machines. Trading in the machinery produced in the CIS countries had practically stopped by this year, except the tractors made in Belarus. They, being certified in accordance with the EU requirements, with the brand 'Belarus', are still traded (purchased) in considerable amounts in Latvia. Table 1 shows variations in the number of the most popular brands of tractors registered in Latvia in the period 2000-2015.

Number of the most popular brands of tractors in 2000-2015

Table 1

\begin{tabular}{|c|c|c|c|c|c|}
\hline No. & Brand of the tractor & $\mathbf{2 0 0 0}$ & $\mathbf{2 0 0 5}$ & $\mathbf{2 0 1 0}$ & $\mathbf{2 0 1 5}$ \\
\hline 1 & Belarus & 375 & 2034 & 3001 & 4088 \\
\hline 2 & John Deere & 14 & 306 & 880 & 1504 \\
\hline 3 & Valtra & 51 & 487 & 1046 & 1481 \\
\hline 4 & The rest produced in the EU & 21 & 365 & 1109 & 2678 \\
\hline 5 & MTZ & 25222 & 25324 & 25449 & 25690 \\
\hline 6 & T-150K & 4272 & 3683 & 3494 & 3325 \\
\hline 7 & K-700 & 751 & 550 & 510 & 443 \\
\hline 8 & T-40 & 14610 & 14645 & 14696 & 14676 \\
\hline 9 & T-25 & 10001 & 9927 & 11105 & 11353 \\
\hline
\end{tabular}

As it is evident, the number of the new certified (Belarus) tractors, which agree with the EU requirements, and the new tractors, made in the EU countries (John Deere, Valtra, the rest), is gradually increasing. The great number of the Belarus tractors is determined by the substantially lower price at the beginning of the period in contrast to the tractors produced in the EU countries, popularity of the brand and cheaper service possibilities. Yet, the tractors of this brand are purchased mainly by small and medium-size peasant farms $[4 ; 5]$. During the period the purchase of these tractors gradually decrease - if in the year 2005 the number of the tractors of the Belarus brand was twice as great as the number of the tractors made in the EU countries, in 2015 the number of tractors produced in the EU countries exceeded the number of the Belarus tractors 1.4 times. This is due to the step-by-step production concentration on larger peasant farms and a demand for more powerful tractors, as well as the higher prices of the Belarus tractors. The most popular (most purchased) tractors made in the EU countries are Valtra and John Deere. In the year 2015 their total number exceeded the number of the other tractors produced in the EU countries. It can be assumed that all the tractors acquired since 2000 are in good technical condition and take part in the production of the product. In their turn, the number of the tractors made in the CIS countries (starting from position 5 in the table) has changed insignificantly (except K-700 and T-150K). The newest of these tractors have been in operation more than 20 years, and their contribution to the production of the product in the period mentioned is diminishing every year with age. In the last years their number is insignificant although they are not excluded from the Register. The age structure of the fleet of tractors has been characterised by the authors previously [4], but the technical condition, in its turn, is analysed in the next chapter.

Because of the great amount of the data to be processed, the data display is chosen for every five years. As $71 \%$ of the purchased tractors, made in the EU countries, are of four brands - Valtra, John Deere, New Holland and Massey Ferguson - for the clarification of their power the data from the STSA Register were analysed about these four brands of tractors assuming that the power of the other tractors produced in the EU countries is similar. The same applies to the tractors of the Belarus brand. 9762 new tractors have been acquired during the period discussed, and from the STSA Register data it is possible to find the brand, model, number and the engine power of the tractors purchased every year. During this period there were bought several thousand used tractors the technical condition and working capacity of which are unknown. It is assumed in the calculations that all the tractors acquired since 2000 are ready to work and are working, and their amortisation period is 15 years. Knowing that all the sowing area mentioned in statistics in the year 2000 was cultivated, the total power of the new 
tractors purchased every year should ensure cultivation of at least the annual increase in the sowing areas and exceed it by 7-8 \% to cover the replacement of the tractors worn out during 15 years.

The average weighted power of one new tractor was calculated from the analysed data in the respective year. Multiplying the calculated average weighted power by the number of tractors purchased during the period we obtain the total power of all the new tractors existing in the country that year. The total power was reduced by $7.5 \%$ to make possible the replacement (amortisation) of the worn-out tractors but increased by $10 \%$, which could approximately characterise the working capacity of the used tractors acquired abroad and the worn-out tractors made in the CIS countries. The increase in the total power should be at least equivalent to the increase in the areas sown. Knowing the total power and the sowing area, it is possible to analyse variations in the specific power. As mentioned in several studies $[4,8]$, the specific power of tractors $\mathrm{kW} \cdot \mathrm{ha}^{-1}$, i.e. the total engine power of all the operating tractors attributed to the sowing area of the agricultural crops, can be an indicator for the estimation of the tractor adequacy for timely and qualitative execution of the field work.

\section{Results and discussion}

During the discussed period 2000 - 2015 peasant farms have purchased 9762 tractors of various brands and power, or, on the average, 650.8 new tractors a year, as well as several hundred used tractors a year. In 2015 the total number of the registered tractors in agriculture was 84074. In contrast to the year 2000, it had grown approximately by 15 thousand. In the age group below 15 years, which should be regarded as the amortisation time, there were about $12 \%$ tractors [4], the average age of a registered tractor being 24.1 years. This indicator depends mainly on the great number of the registered tractors MTZ, T-40 and T-25 (see Table 1), which are considerably older than 20 years. The worn out tractors are not excluded from the Register because their exclusion requires from the owner extra time and costs but a tractor being in the Register does not impose any obligations or liabilities. The present registration procedure remaining, the total number of tractors and the average age of the tractor fleet will continue to increase, creating a wrong impression about energy provision in agriculture.

The working capacity of the tractor fleet is also characterised by its technical condition, which is checked by the STSA once a year. Data about the tractors in good technical condition in percentage from the total number in the particular year are shown in Fig.1. As evident, the number of the tractors in good technical condition is gradually decreasing. During the recent years it constitutes $33-34 \%$ of the total number, except the years 2011 and 2012, because in these years, due to the availability of subsidies, there were purchased more than 1000 new tractors a year, and the purchase of used tractors increased as well.

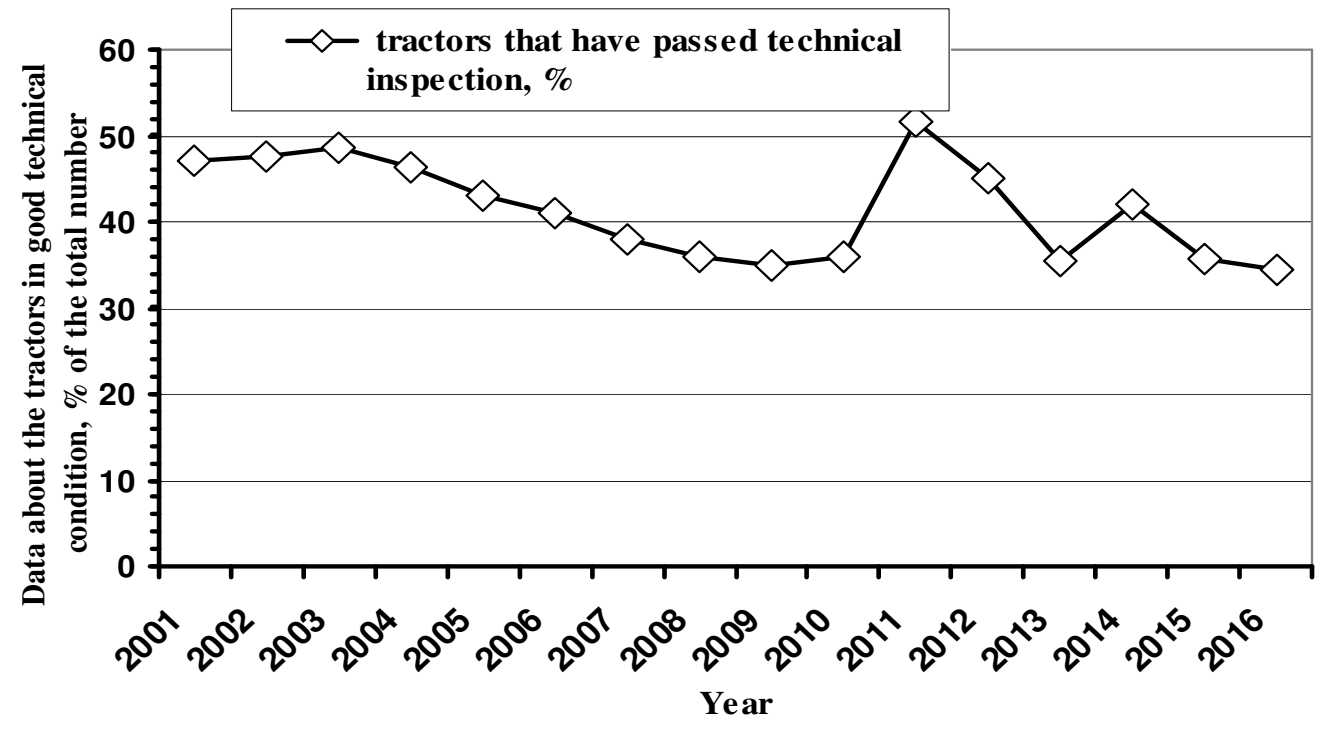

Fig. 1. Data about tractors in good technical condition, $\%$ of the total number

Gradual deterioration of the technical condition of the tractor fleet is the consequence of aging of the fleet. However, 25-26 thousand tractors are in good technical condition every year, which is 
approximately 2.5 times as much as the new (not more than 15 years) tractors. Yet these are lowpower tractors, more than 20 years old (MTZ, T-40, T-25 in Table 1), operating on small peasant farms and on private plots around the farmhouse. They do not take part in the production of goods for the market. Alongside with the technical condition and the age structure of the fleet of tractors, the operating capacity of the fleet is characterised by the total power of its engines. As mentioned in the previous chapter, this indicator is to be discussed together with the entire sowing area of agricultural crops in the respective year. Variations of these two indicators in the period $2000-2016$ are shown in Fig. 2. The area sown during this period has increased 1.34 times, the total power of the tractors increasing 1.48 times. A pre-emptive power increase allows execution of the work in shorter agrotechnical terms, which is important in connection with increasingly extreme climatic conditions, and it provides a possibility to renew the obsolete fleet of tractors as well. When estimating these indicators, one should take into account that the production of products has increased substantially during this period. For instance, growing cereals and canola has increased almost two times.

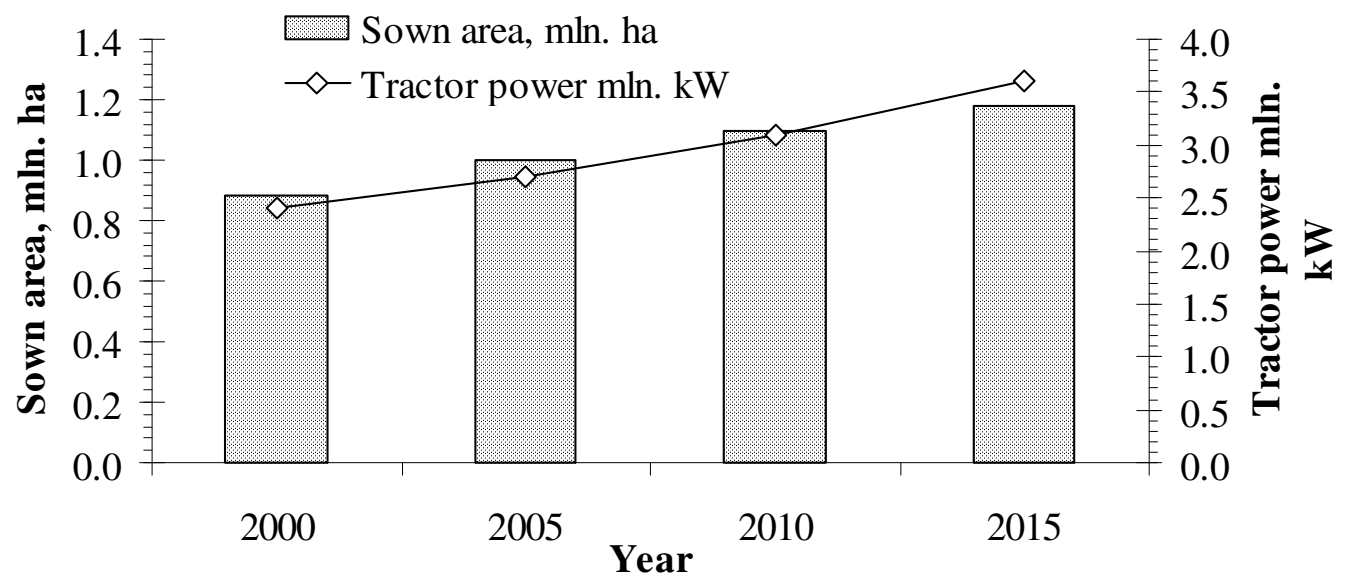

\section{Fig. 2. Variations in sowing areas of agricultural crops and total engine power of the tractor fleet in the period 2000-2015}

Alongside with the total power, as an indicator characterising energy provision in agriculture, several authors $[4,8]$ regard specific power obtained by dividing the total power by the sowing area of agricultural crops in the respective year. According to the data analysis made by the CSB after the survey of several tens of agricultural farms, this indicator, depending on the size and type of the farm producing goods in Latvia, is within a range from 1.30 to $4.10 \mathrm{~kW} \mathrm{ha}^{-1}$ [4]. But according to the data of [8], this indicator in the European countries was 1.06-8.10 kW.ha ${ }^{-1}$, depending on the size of the farm. Variations in the specific tractor power in Latvia in a 15 years' period are shown in Fig. 3.

As it is evident, the specific power has grown from 2.68 to $3.15 \mathrm{~kW} \mathrm{ha}^{-1}$, or 1.18 times. Such an increase is connected both with the increased number of the new tractors (particularly intense it was in 2011-2013), and the increased average weighted power of a new tractor. During 15 years this power has grown from 66.10 to $99.21 \mathrm{~kW}$, or 1.50 times. This increase in the average power of the tractor can be evaluated as small, considering entrance into Latvia of the brands of tractors made in the EU countries. The small increase in the average power is connected with a substantial ratio of the Belarus tractors - from the new 9762 tractors purchased during 15 years 4099, or $42 \%$ are of the Belarus brand. However, the average weighted power of the new tractors of this brand has grown during 15 years only from $63.51 \mathrm{~kW}$ to $71.23 \mathrm{~kW}$, or 1.12 times. Yet, it should be noted that the annual purchase of the tractors of the Belarus brand is decreasing - in the year 2000 there were $88 \%$ of the new tractors, in the year $2005-52 \%$, in the year $2010-28 \%$; in the last year stabilising within the range of $28-32 \%$.

When evaluating the adequacy of the total power of the tractor fleet for the cultivation of the growing sowing areas of agricultural crops, one can state that this increase in the power compensates the increase in the areas, even surpasses it a little, which allows execution of the work in shorter agrotechnical terms. The evaluation does not include the loss of power for the transportation of the increasing amount of the product. 


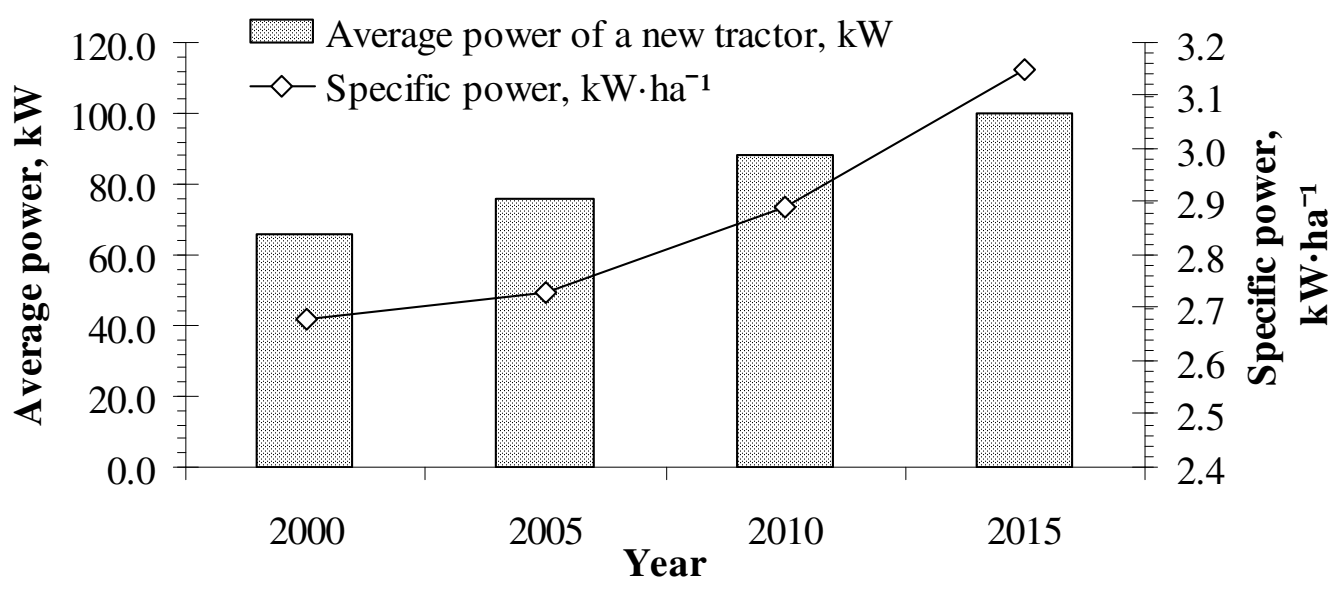

\section{Fig.3. Variations in the specific power of the tractor fleet and average weighted power of a new tractor in the period 2000-2015}

The registration procedure of tractors in the country allows remaining of a large number of obsolete and worn-out tractors in the Register, as a result of which the average age of the tractor fleet increases and the technical condition deteriorates despite the annual acquisition of new tractors. However, the production of goods for the market takes place using highly efficient contemporary machines, the worn-out tractors performing a small amount of work on private plots around the farmhouse. The value of the average specific power can be estimated as relatively high because, as found out in previous studies [4], on the farms with an area above 100 ha the specific power may be considerably lower. As further increase in the sowing areas is expected, upgrading of the tractor fleet should be continued at approximately the same rate - by purchasing, on the average, 600 to 700 new tractors every year.

\section{Conclusions}

1. Because of the great number of worn-out tractors in the Register the average age of tractors is increasing and their technical condition is deteriorating. However, production of the product for the market takes place using up-to-date machines.

2. The increase in the total power of the fleet of tractors during the last 15 years compensates the increase in the sowing area in this period, which allows timely execution of the field work.

3. Production being concentrated on large peasant farms, increase in the average power of a new tractor continues, but the average specific power or energy provision $\mathrm{kW} \cdot \mathrm{ha}^{-1}$ might decrease.

4. Updating of the tractor fleet should be continued at approximately the present rate, purchasing, on the average, 600-700 new tractors a year.

\section{References}

1. LR Centrālās statistikas pārvaldes materiāli 2000... 2015.g. (Materials of the Central Statistic Bureau of Latvia 2000...2015). (In Latvian)

2. Valsts Tehniskās uzraudzības aǵentūras pārskati 2000...2015.g. (Reviews of the State Technical Control Agency 2000...2015.), Rīga, Zemkopības ministrija. (In Latvian)

3. Zemkpības ministrijas Lauku atbalsta dienesta 25.05.2017. informācija Nr.24V "Par datiem pētnieciskajai darbībai" (Ministry of Agriculture, the Rural Support Service 25/05/2017. information Nr.24V "On the data for research."). (In Latvian)

4. Kopiks N., Viesturs D., Valainis O. The Fleet of Tractors on the Farms of Latvia, Its Structure and Energy Intensity. Proceedings of $14^{\text {th }}$ International Scientific Conference "Engineering for Rural Development", Volume 14, Jelgava, 2015, pp. 84-87.

5. Olt J., Traat U., Kuut A. Maintenance Costs of Intensively Used Self-Propelled Machines in Agricultural Companies". Proceedings of $9^{\text {th }}$ International Scientific Conference "Engineering for Rural Development", Jelgava, 2010, pp. 42-48. 
6. Barvicki J., Gach S., Ivanovs S. Proper utilization of soil structure for crops today and conservation for future generations. Proceedings of 11th International Scientific Conference "Engineering for Rural Development", Vol. 11, Jelgava, 2012, pp. 10-15.

7. Kopiks N., Viesturs D.. Investigations in the Suitability of a Fleet of Combines for timely Harvesting. Proceedings of $15^{\text {th }}$ International Scientific Conference "Engineering for Rural Development", Vol. 15, Jelgava, 2016, pp. 681-685.

8. Pawlak J., Pelizzi G., Fiala M. On the Development of Agricultural Mechanization to Ensure a Long-Term World Food Supply. Agricultura /Engineering International: the CIGR Journal of Scientific Research and Development. Invited Overview Paper. Vol. IV.June, 2002, pp. 1-15. 